\title{
Ethnologies
}

\section{Gerald W. Creed. Masquerade and Postsocialism: Ritual and Cultural Dispossession in Bulgaria. (Bloomington: Indiana University Press, 2011. Pp. xi +254, ISBN: 978-0-253-22261-9.)}

\section{Nicholas Hartmann}

Volume 33, numéro 2, 2011

URI : https://id.erudit.org/iderudit/1015034ar

DOI : https://doi.org/10.7202/1015034ar

Aller au sommaire du numéro

Éditeur(s)

Association Canadienne d'Ethnologie et de Folklore

ISSN

1481-5974 (imprimé)

1708-0401 (numérique)

Découvrir la revue

Citer ce compte rendu

Hartmann, N. (2011). Compte rendu de [Gerald W. Creed. Masquerade and Postsocialism: Ritual and Cultural Dispossession in Bulgaria. (Bloomington: Indiana University Press, 2011. Pp. xi +254, ISBN: 978-0-253-22261-9.)].

Ethnologies, 33(2), 245-249. https://doi.org/10.7202/1015034ar d'utilisation que vous pouvez consulter en ligne. 
his own life. As an essay that melds theoretical and practical aspects of the religion, along with politics and migration, all led by a son of Changó, it is a fitting conclusion for this dense, yet rewarding collection.

My only true critiques for this text are: 1) the need for a glossary of Yorùbá terms to aid non-initiates and novices; and 2) the need for greater attention to the role of Sàngó in popular culture. Yorùbá dictionaries are not widely available or necessarily standardized. The editors have taken great care to guarantee that Yorùbá terms are properly presented, and properly spelled according to the vernacular context, yet they have provided little to help readers negotiate this complex territory. While we are given exceedingly detailed histories of Sàngó and largely comprehensive discussions of ritual and function of Sàngó for his followers, the references to his influence on popular culture are mostly skimmed over. As implied in these essays, the power of Sàngó influences the lives of many who are not directly involved with his worship. Throughout much of Nigeria and the diaspora, Sàngó continues to be experienced through a variety of forms of popular culture as well as through non-religious everyday life.

\section{Gerald W. Creed. Masquerade and Postsocialism: Ritual and Cultural Dispossession in Bulgaria}

(Bloomington: Indiana University Press, 2011. Pp. xi +254, ISBN: 978-0-253-22261-9.)

Nicholas Hartmann Memorial University of Newfoundland

A nation subject to much change following the end of communism in 1989, Bulgaria is a complex nation, with multiple ethnicities and a vast cultural heritage that has attracted international attention. Its push to join the European Union (which it successfully did, in 2007) and become part of contemporary Western society brings to 
mind many concerns about Bulgarian society, including concerns for minority protection, economic stability and cultural sustainability. According to the author, anthropologist Gerald W. Creed, such modern concerns and issues can be better understood through what is, in fact, a premodern cultural practice: mumming. According to Creed, it was commonly believed that such practices would lose their relevance to many people with the rise of contemporary postsocialist Bulgarian society. Yet, as his research shows, mumming is not only a growing practice in many communities, but says quite a lot about how postsocialist societies have simultaneously blossomed and floundered in various ways.

A well-organized structure, combined with fairly accessible terminology and explanations of theoretical concepts surrounding postsocialism, allows for Creed's arguments to be understood by more than an anthropologist audience. Discussing aspects of political science, history, ethnic studies and folklore, Masquerade and Postsocialism's first major advantage is its interdisciplinary approach to examining postsocialist folk tradition. This is best seen in the introduction's examination of both postsocialist theory and ritual, the latter of which is said to have risen in value due to the devaluing of many of the practices that maintained communities during the era of communism. Comparing Bulgarian mumming practices with that of the practices examined by scholars such as Halpert and Glassie, the common thought of examining mumming as a locus for social drama and exchange is not only utilized as a framework for later arguments, but also placed into a historical context that demonstrates the perception of mumming as a subversive activity that was forbidden by multiple rulers.

The first chapter, "A Mumming Season," is best seen as a descriptive section, focusing largely on the practices that take place within community mumming and placing them into a cyclical context that demonstrates the connection of mumming to specific times of the year. In addition, the chapter also serves as a place for Creed to differentiate between the terms "ritual" and "festival," as well as the difference in mumming practice that comes with each term. Seeing the ritual as a village-based, communal rite "with supernatural overtones" and "rich in innovation and spontaneity," Creed compares the festival - a large-group setting in which traditional rituals were not 
necessarily fulfilled and often grouped together with other practices during the socialist era as a promoter of nationalism - as being far removed from the tradition, yet nonetheless notable for what it says about Bulgarian history and society.

Gender issues are discussed in the second chapter, "Gender and Sexuality," and a specific emphasis on the connection between mumming and masculinity takes precedence within this part of Creed's book. The role of mumming as a site of male bonding within Bulgarian communities is something that is heavily emphasized due to the connection between mumming and passages to manhood; this is examined within the context of socialist life in Bulgaria, which, along with postsocialism, has been interpreted as an emasculating force in local life. Creed's explanation that socialism was responsible for challenging the political authority of men, and that postsocialism added an economic factor to that, is well explained and provides a better context for the motivations behind the rise of mumming in recent years, as well as the changes that have taken place in regards to the role of women in mumming groups. Furthermore, the explanation of mumming as a cultural process that provides for the safe expression of any form of homoerotic desire is well-established and placed within a larger context of frustration for many Bulgarians: an outside push for same-sex acceptance in the manner of many Western nations.

This push leads into the discussion of other "pushes" by Western society, albeit in the form of pushing Bulgaria towards a more civil society. The third chapter, "Civil Society and Democracy," is a largely theoretical chapter that demonstrates the conflict between late-socialist-era pushes for a civil society and the role of mumming as a force that often reflects upon many aspects of such a society. Seen by many as an "enlightened alternative" to the way things were, civil society, according to Creed, is often at odds with the informal cultural practices that, since the fall of socialism in Bulgaria, have risen dramatically and are often seen by outsiders as unwanted and leading to corruption. Creed's research shows that mummers, in addition to being a force for cultural continuity, also have a role in pushing for political change without necessarily being openly political. In looking at mumming in this way, Creed successfully shows how cultural practices - many of which are often trivialized as archaic are, in fact, vessels for change within communities. 
Socialist society, whose policies often meant that the family developed into a small unit of resistance against the conditions in which its members lived, was seen as a process that eliminated the larger sense of community, and this process is part of the fourth chapter, "Autonomy and Community." According to Creed, such changes in community resulted in changes to mumming practices, such as the place and meaning of masking and the sequence of the ritual itself; in addition, they also demonstrate interdependence among families within a community as being paramount to a family's quest for self-sufficiency. Creed points out that the "representation of these tensions in ritual form" is not necessarily a victim of socialist or postsocialist policies, but rather the framework of social relations on the whole. This suggestion is a clear one that points out the reality that not all community issues in postsocialist Bulgaria are necessarily due to socialist or postsocialist processes.

The fifth chapter, "Ethnicity and Nationalism," brings up important issues dealing with Roma representations in the mumming traditions, focusing largely on the role of Romani in the rise of mumming within many communities. Seen as something that is, for the most, not part of Romani tradition, Creed points out that mumming has, in fact, served as a place for many Romani to gain respect for carrying on a tradition in which many Bulgarians no longer engage themselves. Creed later discusses the comparison of representations of Roma within mumming and the realities of Romani people within Bulgaria, pointing out that the representations of Roma are often so far removed from reality that many Romani see them as being more demeaning to Bulgarians than to the Roma. The economic, social and cultural conditions in which the Roma live are a greater concern, and practices such as blackface more or less serve as a process of differentiation for many Bulgarians; the people, though it might be present, do not consider racism an issue. These processes are often compared to the concerns involving racism in North America and are brought to light as one of many concerns brought upon Bulgaria by outsiders, regardless of whether locals interpret them as such a problem.

In his conclusion, Creed states that many of the issues seen within mumming are, in fact, issues brought up by an outsider's form of modernity (i.e., the European/American point of view). Given that 
mumming has a role "to represent the premodern," it is interesting that Creed's research demonstrated that modernism actually played an important role in keeping this premodern tradition alive; modernity was practically a requirement to keep the tradition alive, and both poverty and instability worked against such sustainability. Such sustainability sits alongside the role of commercialization of mumming, bringing the practice more visibility and financial support in the form of tourism; while seen by some as a negative force, such modern approaches to mumming, according to Creed, are in fact responsible for helping people to reconnect to a past from which they have largely been disconnected. Seen as "modernity in premodern drag," mumming is a process that allows for discussion and debate, and this is well established and explained by Creed in this chapter.

The one major flaw in this book is the scarcity of informants' narratives; while the details of the ritual are quite extensive, the lack of personal experience on the part of informants (as well as the lack of names) makes for distance that hampers the reader's ability to connect more closely with those who mum. Apart from this, the book is thorough yet clear, brings up theoretical concerns while relating them to practice, and demonstrates how folk culture is maintained, changed and discussed within postsocialist society. Combined with the inclusion of local scholarship that combines Eastern European ethnology with North American scholarship, Creed strives to show how ritual is intensified and held in high regard in such societies, and he does so, even if the voice telling the story is largely his. 